\title{
Development of High Quality EST-SSR Markers Without Stutter Bands in Peach and Their Application in Cultivar Discrimination and Hybrid Authentication
}

\author{
Maomao Ding, Ke Wang, and Wenting Wang \\ The State Agriculture Ministry Laboratory of Horticultural Plant Growth, \\ Development and Quality Improvement, Zijingang Campus, Zhejiang \\ University, Hangzhou 310058, People's Republic of China
}

Miaojin Chen and Dajun Wu

Fenghua Institute of Honey Peach, Fenghua 315502, People's Republic of China

\section{Changjie $\mathrm{Xu}^{1}$ and Kunsong Chen \\ Zhejiang Provincial Key Laboratory of Horticultural Plant Integrative Biology, Zijingang Campus, Zhejiang University, Hangzhou 310058, People's Republic of China}

Additional index words. PCR stutter band, slippage amplification, bud sport

\begin{abstract}
Peach (Prunus persica) is an important fruit crop worldwide with several thousand cultivars. Cultivar discrimination and hybrid authentication are often required in peach breeding and can be achieved by applying various molecular markers including simple sequence repeat (SSR). In this study a total of 2146 expressed sequence tag (EST)-SSR loci were detected with the 10,737 EST sequences retrieved from the NCBI. A total of 49 EST-SSR markers, including 24 simple ones with a motif comprising of tri-, tetra-, penta-, hexanucleotides, and 25 compound ones, were selected and then primers were designed. Following conventional polymerase chain reaction (PCR) specificity control and sequence authentication, as well as fluorescence-based PCR product size and stutter band evaluation, 37 EST-SSR markers with correct amplification and without stutter band interference were validated. Among them, 14 were polymorphic in 18 closely related peach accessions, with polymorphism information content (PIC) ranging from 0.0994 to 0.3750 . The 18 peach accessions can be distinguished using nine polymorphic markers, with the exception of 'Shangshandayulu' and 'Xipu 1', both being bud sports from 'Yulu'. The clustering of the accessions as well as the fingerprint profiles supported the authentication of the hybrids. These EST-SSR markers are useful for peach breeding research.
\end{abstract}

Peach is one of the most commercially important and widely distributed fruit crops with several thousand cultivars and the number is increasing ( $\mathrm{Li}$ et al., 2013) with enhanced breeding activities. Peach is believed

\footnotetext{
Received for publication 12 Sept. 2016. Accepted for publication 16 Nov. 2016.

This work was supported by the National High Technology Research and Development Program of China (2013AA102606), the Program of the International Science and Technology Cooperation (2011DFB31580), and the Ningbo Science and Technology Project (2014C10004).

We would like to thank Don Grierson from the University of Nottingham for his efforts in language editing, as well as Chao Feng of South China Botanical Garden, Chinese Academy of Sciences, and Shaoyang Zhang of Tongren University for critical reading of the manuscript.

${ }^{1}$ Corresponding author. E-mail: chjxu@zju.edu.cn.
}

Cipriani et al., 1999; Dirlewanger et al., 2002; Li et al., 2013; Sosinski et al., 2000; Testolin et al., 2000) because of the advantages of ease of operation, high repeatability, accuracy, allelic diversity, and feasibility of transfer between closely related species (Guichoux et al., 2011).

SSRs are regions of repetitive DNA with certain DNA motifs, normally consisting of one to six nucleotides, repeated several times. SSRs are extensively distributed in eukaryotes. In plants, it can be expected to find at least one SSR locus present in every $10 \mathrm{~kb}$ of DNA sequence (Tautz, 1989) and the density was found to be as high as 428.5 per $\mathrm{Mb}$, on average, for eight selected plant species (Cavagnaro et al., 2010). Therefore, numerous SSR loci can be mined to develop SSR markers, especially when genomic or transcriptomic sequencing has been completed. However, for some SSR markers, accurate size identification and allele designation can be difficult due to the presence of stutter bands, or stutter peaks. This problem was encountered in our preliminary study in peach as well as extensively reported in other plants (Caruso et al., 2008; Goulão and Oliveira, 2001; Huang et al., 2000; Jones et al., 1997; Song et al., 2002; Teulat et al., 2000; Wang et al., 2016; Wünsch and Hormaza, 2002). The stutter bands occur as a result of enzyme slippage during amplification and was most common for SSR markers with dinucleotide motifs and the problem is amplified as the repeat number of the alleles increases (Guichoux et al., 2011; Hite et al., 1996). In contrast, markers with motifs consisting of tri- to hexanucleotides, especially when the repeat number is not high, have been shown to be less prone to stuttering problems (Edwards et al., 1991; Goulão and Oliveira, 2001; Song et al., 2002).

In this study, a total of 37 high-quality EST-SSR markers that did not produce stutter bands, consisting of either motifs with at least three nucleotides or compound motifs, were designed and 14 of them were found to be polymorphic in 18 closely related peach accessions, including 10 offsprings from three crosses, studied and therefore useful for peach cultivar discrimination and hybrid authentication.

a narrow genetic base (Cipriani et al., 1999) Some cultivars or lines, especially those from the same breeding parents, are close both genetically and morphologically. The fact that peach is self-fertile makes it important to authenticate the origin of selections to avoid any mistakes in peach cultivar pedigrees.

Peach cultivars were traditionally identified morphologically but this approach proved difficult for closely related cultivars. In recent decades, the identification of cultivars has instead been achieved by using various molecular makers. For example, using restriction fragment length polymorphism and random amplified polymorphic DNA (Chaparro et al., 1994; Quarta et al., 1998; Rajapakse et al., 1995). SSR markers have been used more recently in peach as well (Aranzana et al., 2002; Chen et al., 2014;

\section{Materials and Methods}

Plant materials. Eighteen accessions of peach $[P$. persica (L.) Batsch], including 14 melting peach accessions and four closely related yellow peach accessions, were used in this study (Table 1). The melting peach accessions consist of four commercial cultivars and 10 elite hybrids from crosses between two of these four cultivars as indicated in Table 1 . The hybrids are generated and selected out based on agronomical performances in previous years and hybrid authentication as well as accession discrimination are required. The trees were cultivated at the Fenghua Institute of Honey Peach, Zhejiang province, 
Table 1 . List of 18 peach accessions included in this study.

\begin{tabular}{|c|c|c|c|}
\hline No. & Accession & Note & Parentage/source information \\
\hline 1 & Hakurei & Melting peach & Okubo $\times$ Feichengtao, a cultivar from Japan \\
\hline 2 & Hujingmilu & Melting peach & A cultivar from Wuxi, Jiangsu, China \\
\hline 3 & Shangshandayulu & Melting peach & $\begin{array}{l}\text { A bud sport from 'Yulu' (a cultivar from } \\
\text { Ningbo, Zhejiang, China) }\end{array}$ \\
\hline 4 & Xipu 1 & Melting peach & A bud sport from 'Yulu' \\
\hline 5 & F1-12 & Melting peach & Hujingmilu $\times$ Hakurei \\
\hline 6 & $\mathrm{~F} 1-13$ & Melting peach & Hujingmilu $\times$ Hakurei \\
\hline 7 & F2-7 & Melting peach & Hujingmilu $\times$ Hakurei \\
\hline 8 & F2-18 & Melting peach & Hujingmilu $\times$ Hakurei \\
\hline 9 & F3-1 & Melting peach & Hujingmilu $\times$ Hakurei \\
\hline 10 & F3-10 & Melting peach & Hujingmilu $\times$ Hakurei \\
\hline 11 & $\mathrm{X} 1-15$ & Melting peach & Shangshandayulu $\times$ Hujingmilu \\
\hline 12 & $\mathrm{X} 2-5$ & Melting peach & Shangshandayulu $\times$ Hujingmilu \\
\hline 13 & $\mathrm{X} 2-19$ & Melting peach & Shangshandayulu $\times$ Hujingmilu \\
\hline 14 & $\mathrm{X} 5-20$ & Melting peach & Xipu $1 \times$ Hujingmilu \\
\hline 15 & Fenghuang & Yellow peach & A cultivar from Dalian, Liaoning, China \\
\hline 16 & Jinxiang & Yellow peach & A cultivar from Shanghai, China \\
\hline 17 & Jinxiu & Yellow peach & A cultivar from Shanghai, China \\
\hline 18 & Jinyuan & Yellow peach & A cultivar with Jinxiu as maternal parent \\
\hline
\end{tabular}

China. Young leaves were collected and subsequently frozen in liquid nitrogen and stored at $-80{ }^{\circ} \mathrm{C}$ until use.

DNA extraction. Genomic DNA was extracted using an improved cetyltrimethylammonium bromide protocol as described by Gawel and Jarret (1991). The DNA was purified with a Mag-MK Plant Genomic DNA Extraction kit [Sangon Biotech (Shanghai) Co., Ltd., Shanghai, China] following the manufacturers' instructions and quantified according to absorbance at $260 \mathrm{~nm}$.

Development of new EST-SSR markers. MISA (Thiel et al., 2003; http://pgrc.ipkgatersleben.de/misa/) was used to mine SSR markers from GenBank (http://www. ncbi.nlm.nih.gov/) with the following coefficients: size of PCR products between 100 and $300 \mathrm{bp}$; primer length between 18 and $20 \mathrm{bp}$, annealing temperature $50-65^{\circ} \mathrm{C}$, GC content around $40 \%$ to $70 \%$, optimum $50 \%$; number of repeats no less than five for simple SSR markers consisting of tri to hexanucleotide motifs, and the size between two motifs in a compound SSR marker no more than $100 \mathrm{bp}$.

SSR-PCR amplification. Conventional, or nonlabeled, SSR-PCR amplification was performed for gene cloning. The PCR mixtures contained $10 \mathrm{~mm}$ Tris- $\mathrm{HCl}(\mathrm{pH} 8.3), 50 \mathrm{~mm}$ $\mathrm{KCl}, 10 \mathrm{ng}$ genomic DNA, 5 pmol of each primer, $1.5 \mathrm{mM} \mathrm{MgCl}_{2}, 0.2 \mathrm{~mm}$ of each dNTP, and 0.5 units of Taq DNA polymerase (Vazyme Biotech Co., Ltd.). Amplification was performed in $25 \mu \mathrm{L}$ volumes using an Eppendorf Mastercycler (Eppendorf Scientific, Inc.) with an initial denaturation at $94{ }^{\circ} \mathrm{C}$ for $5 \mathrm{~min}$ followed by 30 cycles of 30 $\mathrm{s}$ at $94{ }^{\circ} \mathrm{C}, 30 \mathrm{~s}$ at $58{ }^{\circ} \mathrm{C}, 30 \mathrm{~s}$ at $72{ }^{\circ} \mathrm{C}$, and a final extension of $7 \mathrm{~min}$ at $72{ }^{\circ} \mathrm{C}$. For fluorescence-based size identification purposes, a fluorescent labeling approach was followed (Schuelke, 2000). The PCR mixtures contained $10 \mathrm{~mm}$ Tris- $\mathrm{HCl}(\mathrm{pH} 8.3)$, $50 \mathrm{~mm} \mathrm{KCl}, 10 \mathrm{ng}$ genomic DNA, 4 pmol forward primer with M13 tail (M13 universal sequence, $5^{\prime}$-TGTAAAACGACGGCCAGT-3') at the $5^{\prime}$-end, 5 pmol of downstream primer, 1 pmol of universal fluorescence dye, either 6-carboxyfluorescein (6-FAM) or 5-hexachloro-fluorescein (HEX), labeled primer, $1.5 \mathrm{~mm} \mathrm{MgCl}_{2}, 0.2 \mathrm{~mm}$ of each dNTP, and 0.5 units of Taq DNA polymerase (Vazyme Biotech Co., Ltd). Amplification was performed in $25 \mu \mathrm{L}$ volumes using an Eppendorf Mastercycler (Eppendorf Scientific, Inc.) with an initial denaturation at $94{ }^{\circ} \mathrm{C}$ for $5 \mathrm{~min}$ followed by 20 cycles of $30 \mathrm{~s}$ at $94{ }^{\circ} \mathrm{C}, 30 \mathrm{~s}$ at $58^{\circ} \mathrm{C}, 30 \mathrm{~s}$ at $72^{\circ} \mathrm{C}$, another 12 cycles of $30 \mathrm{~s}$ at $94{ }^{\circ} \mathrm{C}, 30 \mathrm{~s}$ at $53{ }^{\circ} \mathrm{C}, 30 \mathrm{~s}$ at $72^{\circ} \mathrm{C}$, and a final extension of $7 \mathrm{~min}$ at $72^{\circ} \mathrm{C}$. The primers were synthesized by [Sangon Biotech (Shanghai) Co., Ltd] and the sequences of primers are listed in Table 2.

SSR-PCR product size identification and sequence authentication. Size identification of fluorescence dye-labeled SSR-PCR products was completed by [Sangon Biotech (Shanghai) Co., Ltd] using capillary electrophoresis in an ABI PRISM 3130 DNA Analyser (Applied Biosystems, Foster City, CA). The authentication of SSR-PCR products was analyzed through conventional gene cloning and sequencing (Sambrook et al., 1989).

Data analysis. A (major allele frequency), $N_{a}$ (no. of alleles), $N_{g}$ (no. of genotypes), $H_{e}$ (expected heterozygosity), $H_{o}$ (observed heterozygosity), and PIC was calculated with PowerMarker3.25 (Liu and Muse, 2005). The unweighted paired group method using arithmetic averages was used to construct the phylogenetic tree with TreeView3.2 (Page, 1996).

\section{Results}

Characterization of peach EST-SSR loci. A total of 10,737 EST sequences were retrieved from the NCBI with a total size of $7.36 \mathrm{Mb}$. A total of $2146 \mathrm{EST}-\mathrm{SSR}$ loci were found with a SSR detection rate of $20 \%$ and the distribution density of one SSR locus per $3.43 \mathrm{~kb}$. Near three quarters of the loci detected were simple EST-SSR markers and the remaining consisted of compound SSR markers, defined as the loci located in a UniGene with less than 100 bases between adjacent loci (Table 3). About two-thirds of simple SSR markers contained dinucleotide motifs and one third trinucleotide motifs. Simple EST-SSR markers containing four to six nucleotides were rare, accounting for only $2 \%$ of total loci (Table 3 ).

Development and validation of EST-SSR markers. A total of 49 EST-SSR markers, including 24 simple and 25 compound repeat sequences, with relatively low repeat numbers of motifs, were selected from the tri, tetra-, penta-, hexa-, and compound ESTSSRs and primers were designed (Table 2). The simple dinucleotide EST-SSR markers were excluded from this study because of the higher probability of producing stutter bands during PCR amplification.

Conventional SSR-PCR performed using 'Hujingmilu' peach genomic DNA as template produced specific bands of the expected size for 42 EST-SSR markers (Table 2). Sequence analysis of the 42 EST-SSR markers indicated that 40 of these had over $95 \%$ nucleotide homology with the target sequence deposited in GenBank (Table 2).

For ease of PCR product size analysis, PCR with fluorescent labeled primers were carried out. For most EST-SSR markers, the addition of an M13 tail to the 5'-end of target-specific primer did not affect the authenticity of the amplification (Fig. 1A). The only exception was PPESTSSR21 where PCR products with an unexpected size were amplified (Fig. 1B). Markers PPESTSSR 29 and PPESTSSR 46 produced PCR products of the expected size and stutter bands (Fig. 1C). In summary, 37 EST-SSR markers were valid for further analysis and application (Table 2).

Polymorphism of EST-SSR markers. The polymorphism rate of the 37 EST-SSR markers was evaluated using 18 peach accessions (Table 1). It was found that 23 markers did not possess polymorphism for these closely related accessions. A total of 14 polymorphic markers, with PIC ranging from 0.0994 to 0.3750 , were developed (Table 4).

Accession discrimination and hybrid authentication with EST-SSR markers. According to the unweighted pair group method using arithmetic average clustering of the results, the 18 peach accessions could all be distinguished, with the exception of 'Shangshandayulu' and 'Xipu 1', both of which are bud sports from 'Yulu' (Fig. 2). These accessions were separated into two groups, with yellow peach types in Group I and melting peach types in Group II, which was divided into subgroups. 'Jinyuan', a progeny of 'Jinxiu', clustered together with 'Jinxiu' in subgroup I-B. The melting peach accessions were separated into two subgroups, with 'Hujingmilu', 'Hakurei' and their progenies in subgroup II-A and 'Xipu 1', 'Shangshandayulu' and their progenies, with either as maternal parent and 'Hujingmilu' as paternal one, in subgroup II-B. Clustering of progenies with 

markers. ${ }^{z}$

\begin{tabular}{|c|c|c|c|c|c|c|c|c|}
\hline Marker & Repeat motif & $\begin{array}{l}\text { PCR } \\
\text { product } \\
\text { (bp) }\end{array}$ & Primer sequence $\left(5^{\prime}-3^{\prime}\right)$ & $\begin{array}{l}\mathrm{Ta} \\
\left({ }^{\circ} \mathrm{C}\right)\end{array}$ & GenBank & $\begin{array}{c}\text { PCR } \\
\text { specificity } \\
\text { control } \\
\end{array}$ & $\begin{array}{c}\text { Sequence } \\
\text { authentication }\end{array}$ & $\begin{array}{c}\text { Size } \\
\text { and } \\
\text { stutter } \\
\text { band } \\
\text { check }\end{array}$ \\
\hline$\overline{\text { PPESTSSR1 }}$ & $\left(\mathrm{GATG}_{5}\right.$ & 260 & $\begin{array}{l}\text { F:TACTGCGGGAAGCAGGTCCCAA } \\
\text { R:GAGGATGTGGAAGAAGGCAAGTAGC }\end{array}$ & 58 & XM_007220467 & $\mathrm{P}$ & $\mathrm{P}$ & $\mathrm{P}$ \\
\hline PPESTSSR2 & $(\mathrm{AAAG})_{5}$ & 240 & $\begin{array}{l}\text { F:ATGTGTCAGACCTCCGCCCGAA } \\
\text { R:TTCGGAGATCCGTTTCCGGCCA }\end{array}$ & 58 & XM_007202582 & $\mathrm{P}$ & $\mathrm{P}$ & $\mathrm{P}$ \\
\hline PPESTSSR 3 & $(\mathrm{CCTC})_{5}$ & 259 & $\begin{array}{l}\text { F:TCCACCTCGAACCTCTCTCCTCA } \\
\text { R:CAGCTGCTTACCCACCAACCCA }\end{array}$ & 58 & XM_007203613 & $\mathrm{P}$ & $P$ & $\mathrm{P}$ \\
\hline PPESTSSR4 & $(\mathrm{TTTC})_{5}$ & 174 & $\begin{array}{l}\text { F:GACGGTACGGTGCATGGTGCTA } \\
\text { R:ATCGATCCCCCGTCTGCAACCA }\end{array}$ & 58 & XM_007222688 & $\mathrm{P}$ & $\mathrm{P}$ & $\mathrm{P}$ \\
\hline PPESTSSR5 & $(\mathrm{ACA})_{6} \mathrm{~N}_{79}(\mathrm{CAA})_{6}$ & 300 & $\begin{array}{l}\text { F:TGTGCTTGGAAGGAGGGGCTGA } \\
\text { R:ACCCCTCCATCTTGGGCCTTCT }\end{array}$ & 58 & XM_007227482 & $\mathrm{P}$ & $\mathrm{P}$ & $\mathrm{P}$ \\
\hline PPESTSSR6 & $(\mathrm{ATAA})_{5}$ & 215 & $\begin{array}{l}\text { F:TAGAGGGGTGGCTGGCCTTAGA } \\
\text { R:GCACGTGATGGGAACCTGAGTTCG }\end{array}$ & 58 & AJ875748 & $\mathrm{F}$ & 1 & / \\
\hline PPESTSSR7 & $(\mathrm{CCCT})_{5}$ & 192 & $\begin{array}{l}\text { F:AGGGGAAAAAGGGAAGGAGCCCA } \\
\text { R:TCCGGCTCCCAATTTTTGGCCC }\end{array}$ & 58 & DY653960 & $\mathrm{F}$ & l & l \\
\hline PPESTSSR8 & $(\mathrm{ATCC})_{5}$ & 223 & $\begin{array}{l}\text { F:TCGACACACCAGCAGAGAGACCA } \\
\text { R:GCGAGAAATGCACCGCTGAGGA }\end{array}$ & 58 & DY649221 & $\mathrm{P}$ & $\mathrm{P}$ & $\mathrm{P}$ \\
\hline PPESTSSR9 & $(\mathrm{GGCAA})_{7}$ & 162 & $\begin{array}{l}\text { F:GGATGAAGCGCGCAAGAAACGC } \\
\text { R:ATGCCCCGACCTTGGCTTACCT }\end{array}$ & 58 & DN554956 & $\mathrm{F}$ & l & / \\
\hline PPESTSSR 10 & $(\text { GGTGAA })_{5}$ & 270 & $\begin{array}{l}\text { F:GGGATACAGGGGTAGTGGGGTGTT } \\
\text { R:TTCGGGTCGGCGTCGTAGAGTT }\end{array}$ & 58 & XM_007205282 & $\mathrm{F}$ & I & / \\
\hline PPESTSSR11 & $(\mathrm{CAACGG})_{5}$ & 220 & $\begin{array}{l}\text { F:CAATGGCAGTGGCGGTGGTCTT } \\
\text { R:ATTGGTGCCAACATGTCCCGCC }\end{array}$ & 58 & XM_007215646 & $\mathrm{P}$ & $\mathrm{P}$ & $\mathrm{P}$ \\
\hline PPESTSSR12 & $(\text { TCATCT })_{6}$ & 132 & $\begin{array}{l}\text { F:CACTTGCACCGTTGACTTGCGG } \\
\text { R:AATGGGTTGAAAGGGCATTCTTCTTCT }\end{array}$ & 58 & DN553995 & $\mathrm{P}$ & $\mathrm{P}$ & $\mathrm{P}$ \\
\hline PPESTSSR13 & $(\mathrm{TAGAGG})_{7}$ & 220 & $\begin{array}{l}\text { F:AGCCGCACAGGAACAGGACTCT } \\
\text { R:TCTGGGGCTGCCCTCATAATCTT }\end{array}$ & 58 & DY653540 & $\mathrm{P}$ & $\mathrm{P}$ & $\mathrm{P}$ \\
\hline PPESTSSR14 & $(\mathrm{GATAGG})_{5}$ & 104 & $\begin{array}{l}\text { F:ATTCGAGCTGGCTCGGCATCTG } \\
\text { R:ACTCGTTCCCTTTCCCTTTCCCT }\end{array}$ & 58 & DY642263 & $\mathrm{P}$ & $P$ & $\mathrm{P}$ \\
\hline PPESTSSR 15 & $(\mathrm{GGACAG})_{5}$ & 244 & $\begin{array}{l}\text { F:ACGCCCACCTTCTGTGAAAGCG } \\
\text { R:TCGATTCCGATCCCGGTCCCTT }\end{array}$ & 58 & DY640145 & $\mathrm{P}$ & $\mathrm{P}$ & $\mathrm{P}$ \\
\hline PPESTSSR16 & $(\mathrm{TTC})_{5}$ & 100 & $\begin{array}{l}\text { F:TCTCCAGCATCAGCATTTTCAACCGC } \\
\text { R:TGTGGAAGCAGAAGAGGAACCCGT }\end{array}$ & 58 & AJ873677 & $\mathrm{P}$ & $\mathrm{P}$ & $\mathrm{P}$ \\
\hline PPESTSSR17 & $(\mathrm{CTC})_{5}$ & 103 & $\begin{array}{l}\text { F:CGTTGTGTCTGCCGGAAACGGA } \\
\text { R:CGAACAAATCGACCGACGCCGA }\end{array}$ & 58 & DY636273 & $\mathrm{P}$ & $\mathrm{P}$ & $\mathrm{P}$ \\
\hline PPESTSSR 18 & $(\mathrm{ATG})_{5}$ & 104 & $\begin{array}{l}\text { F:TTGGTGGGGGCTGAGAGGGTTA } \\
\text { R:ACCTGTGCCACCTCCCCAATCA }\end{array}$ & 58 & XM_007222928 & $\mathrm{P}$ & $\mathrm{P}$ & $P$ \\
\hline PPESTSSR19 & $(\mathrm{TGG})_{5}$ & 104 & $\begin{array}{l}\text { F:GCATGGGCGAAACATTCGCGTC } \\
\text { R:AATAGCCACCATCCCCGCGGTA }\end{array}$ & 58 & XM_007227499 & $\mathrm{P}$ & $\mathrm{P}$ & $\mathrm{P}$ \\
\hline PPESTSSR 20 & $(\mathrm{TGC})_{6}$ & 105 & $\begin{array}{l}\text { F:CCCCACTTTGTGGTTGCTGTTGC } \\
\text { R:AGCAGCAGCATCAGTTTCAGCA }\end{array}$ & 58 & XM_007222318 & $\mathrm{P}$ & $\mathrm{P}$ & $\mathrm{P}$ \\
\hline PPESTSSR 21 & $(\mathrm{ACC})_{8}$ & 105 & $\begin{array}{l}\text { F:ACAGCAGCATCAGCAGCAGCAA } \\
\text { R:ATTGTTCTGAGGCGGCGGAGGA }\end{array}$ & 58 & XM_007218171 & $\mathrm{P}$ & $\mathrm{P}$ & $\mathrm{F}$ \\
\hline PPESTSSR22 & $(\mathrm{CGA})_{5}$ & 105 & $\begin{array}{l}\text { F:ACCAAAACACCCTCTTGCCCTTC } \\
\text { R:TGGCAGCAATGTAGCTGAGGCG }\end{array}$ & 58 & AM291495 & $\mathrm{P}$ & $\mathrm{P}$ & $\mathrm{P}$ \\
\hline PPESTSSR23 & $(\mathrm{CTT})_{6}$ & 108 & $\begin{array}{l}\text { F:AGACGCAGACATGGCTGAACCC } \\
\text { R:CACCGGTGAACCGAACCAGCTT }\end{array}$ & 58 & DY654242 & $\mathrm{P}$ & $P$ & $P$ \\
\hline PPESTSSR24 & $(\mathrm{AAC})_{9}$ & 109 & $\begin{array}{l}\text { F:ACTTTCACTGCTGCCCTTGCCG } \\
\text { R:TGTTGTTGGAGGTCGTCGAGGC }\end{array}$ & 58 & XM_007213885 & $\mathrm{P}$ & $\mathrm{P}$ & $\mathrm{p}$ \\
\hline PPESTSSR25 & $(\mathrm{GAT})_{5}$ & 112 & $\begin{array}{l}\text { F:TCAGCTAGAGCATGATGGGCAGGA } \\
\text { R:TGATGATCGCCCACTACCGCCT }\end{array}$ & 58 & DY636999 & $\mathrm{P}$ & $\mathrm{P}$ & $\mathrm{P}$ \\
\hline PPESTSSR26 & $(\mathrm{TC})_{13} \mathrm{~A}(\mathrm{CT})_{7}$ & 140 & $\begin{array}{l}\text { F:TTCCCGTTCAATGCCGTGCCTC } \\
\text { R:AGTCGATGCTGAACCCTCCGCT }\end{array}$ & 58 & XM_007209191 & $\mathrm{P}$ & $\mathrm{F}$ & 1 \\
\hline PPESTSSR 27 & $(\mathrm{CT})_{6} \mathrm{~N}_{46}(\mathrm{TC})_{8}$ & 162 & $\begin{array}{l}\text { F:TGCCTCCACCACCTCTCACTCT } \\
\text { R:CCACTCCCCCGACAGTGCTAGTTA }\end{array}$ & 58 & DN553995 & $\mathrm{P}$ & $\mathrm{P}$ & $\mathrm{P}$ \\
\hline PPESTSSR 28 & $(\mathrm{CT})_{12} \mathrm{~N}_{40}(\mathrm{TC})_{8}$ & 164 & $\begin{array}{l}\text { F:TCTCAATGTCTGCCTCAACCACCC } \\
\text { R:TGGTGGCTCTTGATTGGCCGTG }\end{array}$ & 58 & DY636694 & $\mathrm{P}$ & $\mathrm{P}$ & $\mathrm{P}$ \\
\hline PPESTSSR29 & $(\mathrm{CT})_{22} \mathrm{~N}_{38}(\mathrm{CT})_{6}$ & 180 & $\begin{array}{l}\text { F: GCAACCTCCTCTCCCCAAACCA } \\
\text { R: TGAGAGAGAGCGAGAGTGACCGT }\end{array}$ & 58 & XM_007227250 & $\mathrm{P}$ & $\mathrm{P}$ & $\mathrm{F}$ \\
\hline PPESTSSR30 & $(\mathrm{CTGT})_{5} \mathrm{~N}_{9}(\mathrm{TC})_{7}$ & 181 & $\begin{array}{l}\text { F:TCCTGTACCGTCCACGCTCTCT } \\
\text { R:GAAGGCCGCGGACAACGAAAGA }\end{array}$ & 58 & XM_007202079 & $\mathrm{P}$ & $\mathrm{P}$ & $\mathrm{P}$ \\
\hline PPESTSSR 31 & $(\mathrm{CT})_{7} \mathrm{~N}_{93}(\mathrm{ACC})_{5}$ & 182 & $\begin{array}{l}\text { F:AGCCAGCCCTGCTCTCTCAACT } \\
\text { R:TGTGGCCACTTTCCGACAGGGA }\end{array}$ & 58 & XM_007203458 & $\mathrm{P}$ & $\mathrm{P}$ & $\mathrm{P}$ \\
\hline PPESTSSR 32 & $(\text { CTCTTC })_{5} \mathrm{~N}_{72}(\text { TCA })_{5}$ & 187 & $\begin{array}{l}\text { F:ACCCCATTGAAGCTGGAGAAGCTC } \\
\text { R: GTCGTTTTGGAGGCGGCCATGA }\end{array}$ & 58 & DY640665 & $\mathrm{P}$ & $\mathrm{P}$ & $P$ \\
\hline PPESTSSR33 & $(\mathrm{CT})_{8} \mathrm{~T}(\mathrm{TC})_{6}$ & 216 & $\begin{array}{l}\text { F:CCTCCGTTGACATCATTTCACCACACC } \\
\text { R:TTTTTGGAGGGAAGGGCCGGGA }\end{array}$ & 58 & DY646029 & $\mathrm{P}$ & $\mathrm{P}$ & $\mathrm{P}$ \\
\hline
\end{tabular}


Table 2. (Continued) List of primer sequences, repeat motif information, PCR product size, PCR annealing temperature (Ta) and GenBank accession numbers for 49 EST-SSR markers. ${ }^{z}$

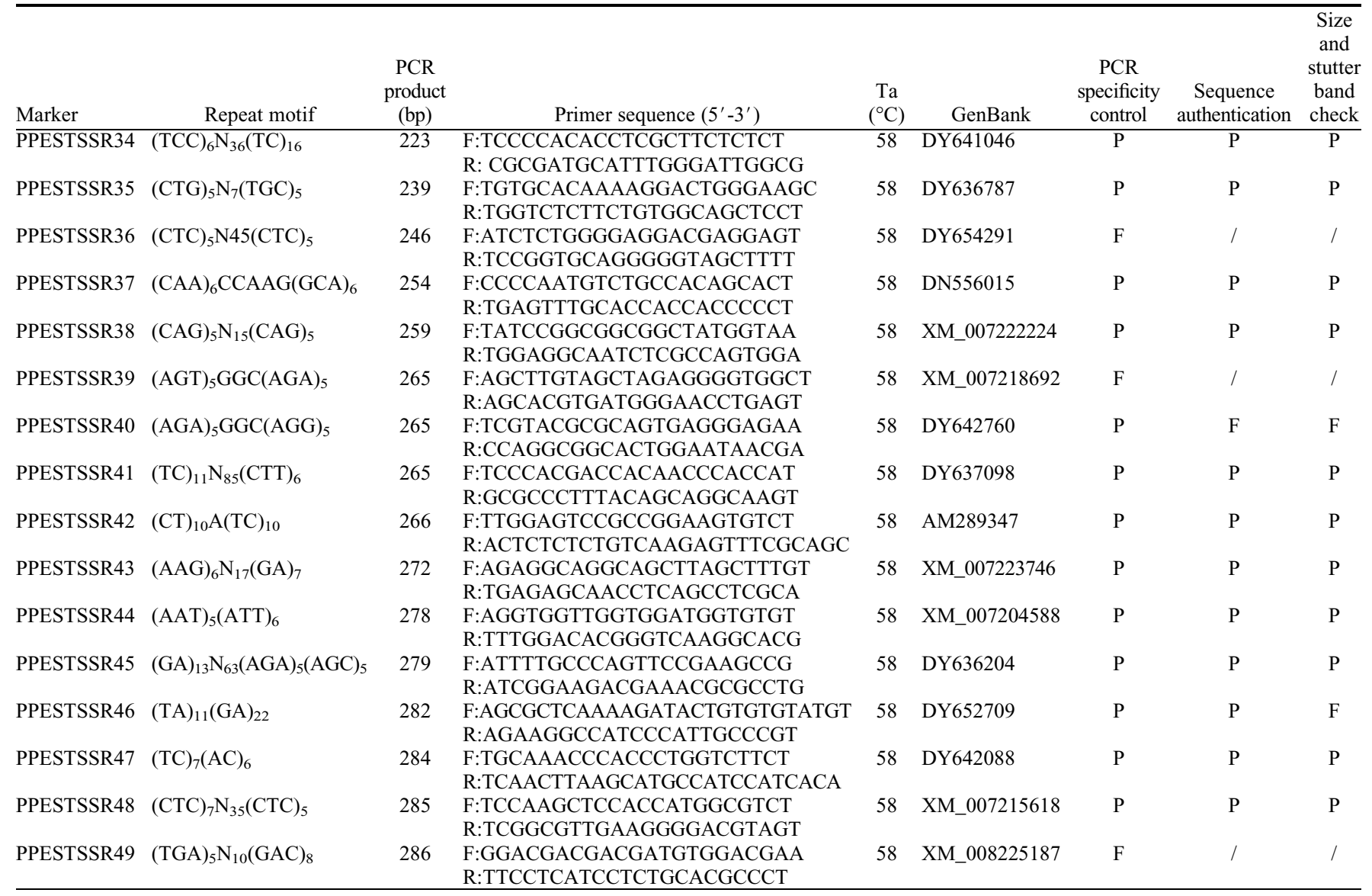

$\mathrm{PCR}=$ polymerase chain reaction; $\mathrm{EST}=$ expressed sequence tag; $\mathrm{SSR}=$ simple sequence repeat.

${ }^{\mathrm{z}} \mathrm{P}, \mathrm{F}$ and / in right three columns indicates passed, failed, and not analyzed, respectively.

Table 3. Constitution of 2146 EST-SSR loci derived from the EST sequences deposited in GenBank.

\begin{tabular}{|c|c|c|c|c|c|c|c|c|c|c|c|}
\hline \multirow[b]{2}{*}{ Motif } & \multicolumn{10}{|c|}{ No. of repeats } & \multirow[b]{2}{*}{ Total (\%) } \\
\hline & 6 & 7 & 8 & 9 & 10 & 11 & 12 & 13 & 14 & $>14$ & \\
\hline$\overline{\mathrm{AG} / \mathrm{CT}}$ & 96 & 64 & 41 & 35 & 23 & 17 & 19 & 25 & 27 & 141 & $488(22.74)$ \\
\hline GA/TC & 79 & 46 & 31 & 22 & 14 & 16 & 15 & 13 & 15 & 118 & 369 (17.19) \\
\hline Other 2-nt & 45 & 21 & 16 & 10 & 7 & 7 & 13 & 6 & 6 & 6 & $137(6.38)$ \\
\hline \multirow[t]{2}{*}{ Total } & 220 & 131 & 88 & 67 & 44 & 40 & 47 & 44 & 48 & 265 & 994 (46.32) \\
\hline & 5 & 6 & 7 & 8 & 9 & 10 & 11 & 12 & 13 & 14 & \\
\hline AAG/AGA & 31 & 7 & 2 & 2 & 0 & 2 & 1 & & & 1 & $46(2.14)$ \\
\hline $\mathrm{AGC} / \mathrm{CAA}$ & 16 & 11 & 3 & 3 & 1 & & & & & & $34(1.58)$ \\
\hline $\mathrm{CAG} / \mathrm{CAT}$ & 20 & 7 & 5 & 11 & 2 & & 1 & 1 & & & $47(2.19)$ \\
\hline $\mathrm{CCA} / \mathrm{CTC}$ & 19 & 4 & 6 & 1 & & & & & & & $30(1.4)$ \\
\hline CTG/CTT & 29 & 6 & 4 & 8 & 5 & 5 & & & & & $57(2.66)$ \\
\hline GAA/GCT & 22 & 15 & 3 & 3 & & 1 & & & & & $44(2.05)$ \\
\hline $\mathrm{TCT} / \mathrm{TTC}$ & 21 & 19 & 1 & 2 & & & & & & & $44(2.05)$ \\
\hline Other 3-nt & 124 & 60 & 21 & 11 & 8 & 3 & 3 & 2 & & & $232(10.81)$ \\
\hline \multirow{2}{*}{ Total } & 282 & 129 & 45 & 41 & 16 & 11 & 6 & 3 & & 1 & $534(24.88)$ \\
\hline & 5 & 6 & 7 & 8 & 9 & & & & & & \\
\hline 4-nt & 18 & 2 & & & & & & & & & $20(0.93)$ \\
\hline 5 -nt & 4 & 2 & 1 & & 2 & & & & & & $9(0.42)$ \\
\hline 6-nt & 7 & 3 & 2 & & & & & & & & $12(0.56)$ \\
\hline Total & 29 & 7 & 3 & & 2 & & & & & & $41(1.91)$ \\
\hline Compound & & & & & & & & & & & $577(26.89)$ \\
\hline
\end{tabular}

$\mathrm{EST}=$ expressed sequence tag; $\mathrm{SSR}=$ simple sequence repeat.

either parent was observed (Fig. 2). The authentication of hybrids was supported by the fingerprint profiles where the SSR bands of progenies were covered by at least one parents (Table 5).
The minimum number of EST-SSR markers required for separation of these accessions, excepting 'Shangshandayulu' and 'Xipu 1', was reduced to nine, based on the recorded SSR product sizes (Table 5).

\section{Discussion}

Application of EST-SSR markers in peach accession discrimination. SSR markers were present in both transcribed and nontranscribed sequences, and were named as EST-SSRs and genomic SSRs, respectively. Historically, genomic SSRs were developed earlier, from the late 1980s, and EST-SSRs became predominant from the era of nextgeneration sequencing (Guichoux et al., 2011). For peach, the development of the first set of genomic SSRs was reported in the closing years of the last century (Cipriani et al., 1999; Testolin et al., 2000) while most EST-SSR literature began to appear 5 years later with the availability of ESTs deposited in GenBank (Chen et al., 2014; Vendramin et al., 2007; Xu et al., 2004).

Here, with the public EST information from NCBI, 37 EST-SSR markers were developed. Since the genetic background of the accessions applied in this study is narrow, especially, 10 hybrids from three crosses were included. Therefore, the 14 markers possessing polymorphism for these closely related accessions are expected to be generally valid for other peach accession discrimination and hybrid authentication as well. Besides, though 23 of these were not polymorphic applied to the 18 closely related peach accessions, these markers can be useful 


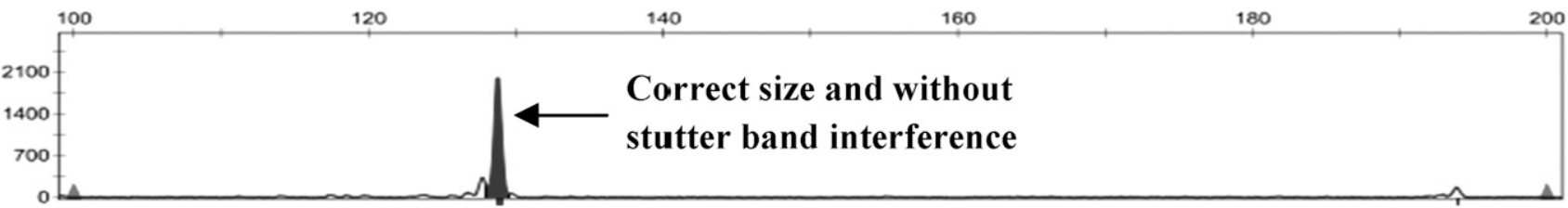

B

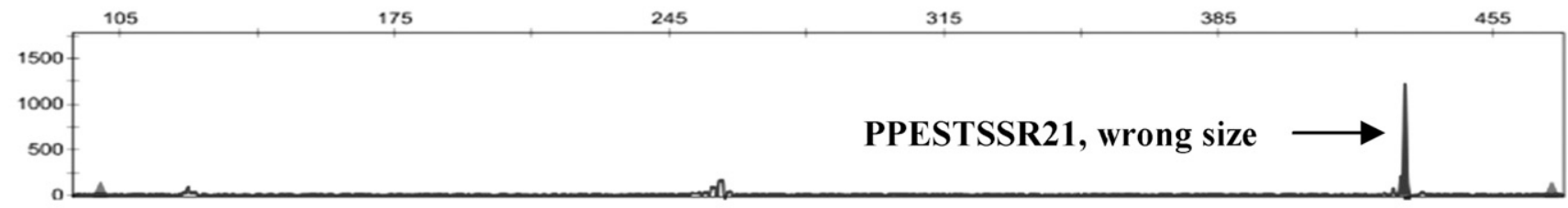

C

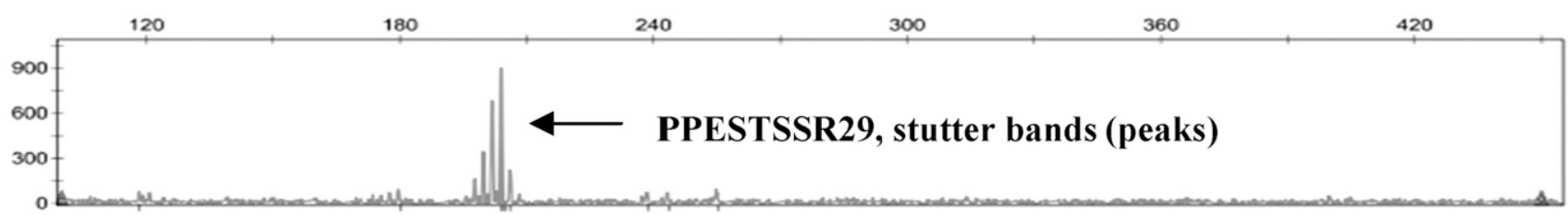

Fig. 1. Representative electropherogram profiles of fluorescence-labeled simple sequence repeat products of (A) correct size and without stutter band interference, (B) wrong size, or $(\mathbf{C})$ with stutter band interference.

Table 4. Characteristics of the 14 polymorphic EST-SSR markers validated with 18 peach accessions.

\begin{tabular}{lcllccc}
\hline Marker & $\mathrm{A}^{\mathrm{z}}$ & $N_{\mathrm{a}}$ & $N_{\mathrm{g}}$ & $H_{\mathrm{o}}$ & $H_{\mathrm{e}}$ & PIC \\
\hline PPESTSSR15 & 0.5000 & 2 & 3 & 0.5556 & 0.5000 & 0.3750 \\
PPESTSSR32 & 0.5000 & 2 & 3 & 0.4444 & 0.5000 & 0.3750 \\
PPESTSSR43 & 0.5000 & 2 & 3 & 0.3333 & 0.5000 & 0.3750 \\
PPESTSSR34 & 0.7222 & 3 & 3 & 0.5556 & 0.4151 & 0.3490 \\
PPESTSSR11 & 0.6944 & 2 & 2 & 0.6111 & 0.4244 & 0.3343 \\
PPESTSSR48 & 0.6944 & 2 & 3 & 0.3889 & 0.4244 & 0.3343 \\
PPESTSSR13 & 0.8056 & 2 & 2 & 0.3889 & 0.3133 & 0.2642 \\
PPESTSSR24 & 0.8333 & 2 & 2 & 0.3333 & 0.2778 & 0.2392 \\
PPESTSSR30 & 0.8611 & 2 & 2 & 0.2778 & 0.2392 & 0.2106 \\
PPESTSSR33 & 0.8889 & 2 & 2 & 0.2222 & 0.1975 & 0.1780 \\
PPESTSSR20 & 0.9167 & 2 & 2 & 0.1667 & 0.1528 & 0.1411 \\
PPESTSSR28 & 0.9167 & 2 & 3 & 0.0556 & 0.1528 & 0.1411 \\
PPESTSSR44 & 0.9167 & 2 & 2 & 0.1667 & 0.1528 & 0.1411 \\
PPESTSSR14 & 0.9444 & 2 & 2 & 0.1111 & 0.1049 & 0.0994 \\
Mean & 0.7639 & 2.0714 & 2.4286 & 0.3294 & 0.3111 & 0.2541 \\
\hline A
\end{tabular}

${ }^{\mathrm{z}} \mathrm{A}=$ major allele frequency; $N_{a}=$ number of alleles; $N_{g}=$ Number of genotypes; $H_{o}=$ observed heterozygosity; $H_{e}=$ expected heterozygosity; $\mathrm{PIC}=$ polymorphism information content; $\mathrm{EST}=$ expressed sequence tag; SSR = simple sequence repeat.

for other studies when accessions with broader biodiversity are being studied. One of the main advantages of EST-SSRs over genomic SSRs is the high levels of transferability, i.e., the EST-SSRs can be transferred across closely related species (Guichoux et al., 2011). Therefore, the EST-SSRs developed here are likely to be easily transferred to other Prunus species as found with the cases described by Vendramin et al. (2007).

Discrimination between bud sports, or clones, with molecular markers remains a challenging task for breeding research. As described by Monte-Corvo et al. (2001), none of the five types of molecular markers, including SSRs, succeeded in identification of nine 'Rocha' pear clones. Similarly, four types of molecular markers, including SSRs, failed to detect genetic variations between 'Shatangju' 2012). In peach, with 26 SSR markers, several sports as well as two pairs of cultivars were not successfully discriminated (Testolin et al., 2000). Here, with the 37 EST-SSR markers, it was not possible to discriminate Shangshandayulu and Xipu 1 peach accessions, two bud sports from 'Yulu', suggesting more EST-SSR markers are needed. Alternatively, other molecular markers like interretrotransposon amplified polymorphisms, inter-SSRs, sequence-related amplified polymorphism, and sequencespecific amplification polymorphism, successful cases of which have been reported previously, can be tried (Huang et al., 2012; Sun et al., 2015; Zhao et al., 2010).

Key points for obtaining high-quality EST-SSR markers without interference from stutter bands. As described in Introduction section, the stutter band interference for and its sport 'Wuzishatangju' (Huang et al.,
SSR-PCR product size identification occurs frequently. This was also encountered in our preliminary studies with some peach SSR markers reported previously. As shown in Figure 1, such interference makes the correct allele designation difficult (Guichoux et al., 2011).

Stutter bands occur as a result of enzyme slippage during amplification (Hite et al., 1996; Guichoux et al., 2011). Occurrence of stutter bands has been related to the features of some markers themselves, including the number of nucleotides in the motif and the number of repeats, as well as PCR amplification conditions and changes in reaction conditions, such as the use of new-generation polymerase, changes in PCR temperature regimes, and reduction in amount of template DNA, have been proposed to reduce stuttering (Guichoux et al., 2011; Hite et al., 1996; Olejniczak and Krzyzosiak 2006; Seo et al., 2014). Some of these were tested in our preliminary studies and it was found that the application of high-fidelity Pfu DNA polymerase, the application of purified template DNA, and the reduction in amount of template DNA did not obviously reduce the stuttering interference (data not shown).

The most effective way to avoid the stuttering problem we found is the selection of suitable SSR motifs. As the interference was especially serious with dinucleotide motifs and exaggerated as the repeat number increased (Edwards et al., 1991; Guichoux et al., 2011; Hite et al., 1996), in this study simple EST-SSRs with dinucleotide motifs were excluded for marker development. Most selected markers were free of stutter bands, except for two compound EST-SSRs, PPESTSSR29 and PPESTSSR46 (Fig. 1), 


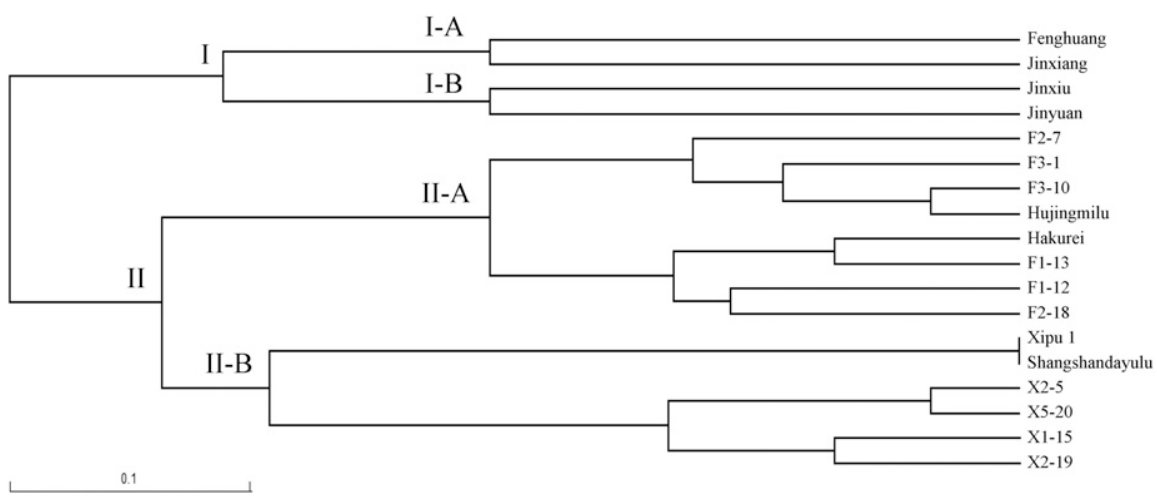

Fig. 2. Dendrogram for 18 peach accessions derived by the unweighted pair group method using arithmetic average cluster analysis based on 14 polymorphic expressed sequence tag-simple sequence repeat markers.

Table 5. Digital fingerprint of 18 peach accessions from 14 EST-SSR markers.

\begin{tabular}{|c|c|c|c|c|c|c|c|c|c|c|c|c|c|c|c|c|c|c|}
\hline \multirow[b]{2}{*}{ Marker } & \multirow{2}{*}{$\begin{array}{c}\text { PCR } \\
\text { product (bp) }\end{array}$} & \multicolumn{17}{|c|}{ Accession $^{y}$} \\
\hline & & 1 & 2 & $3 / 4$ & 5 & 6 & 7 & 8 & 9 & 10 & 11 & 12 & 13 & 14 & 15 & 16 & 17 & 18 \\
\hline \multirow{2}{*}{ PPESTSSR $11^{* z}$} & 233 & 1 & 1 & 1 & 1 & 1 & 1 & 1 & 1 & 1 & 1 & 1 & 1 & 1 & 1 & 1 & 1 & 1 \\
\hline & 239 & 0 & 1 & 0 & 0 & 0 & 1 & 0 & 1 & 0 & 1 & 1 & 1 & 1 & 1 & 1 & 1 & 1 \\
\hline \multirow[t]{2}{*}{ PPESTSSR13* } & 233 & 1 & 1 & 1 & 1 & 1 & 1 & 1 & 1 & 1 & 1 & 1 & 1 & 1 & 1 & 1 & 1 & 1 \\
\hline & 239 & 0 & 0 & 1 & 0 & 0 & 0 & 0 & 0 & 0 & 1 & 0 & 1 & 0 & 0 & 1 & 1 & 1 \\
\hline \multirow[t]{2}{*}{ PPESTSSR 14} & 117 & 0 & 0 & 0 & 0 & 0 & 0 & 0 & 0 & 0 & 0 & 0 & 0 & 0 & 0 & 0 & 1 & 1 \\
\hline & 123 & 1 & 1 & 1 & 1 & 1 & 1 & 1 & 1 & 1 & 1 & 1 & 1 & 1 & 1 & 1 & 1 & 1 \\
\hline \multirow[t]{2}{*}{ PPESTSSR15* } & 257 & 0 & 1 & 1 & 0 & 0 & 1 & 1 & 1 & 1 & 1 & 1 & 0 & 1 & 1 & 1 & 1 & 1 \\
\hline & 263 & 1 & 1 & 1 & 1 & 1 & 1 & 1 & 1 & 1 & 0 & 0 & 1 & 0 & 1 & 1 & 1 & 0 \\
\hline \multirow[t]{2}{*}{ PPESTSSR20 } & 112 & 1 & 0 & 0 & 0 & 0 & 0 & 0 & 1 & 0 & 0 & 0 & 0 & 0 & 0 & 0 & 1 & 0 \\
\hline & 124 & 1 & 1 & 1 & 1 & 1 & 1 & 1 & 1 & 1 & 1 & 1 & 1 & 1 & 1 & 1 & 1 & 1 \\
\hline \multirow[t]{2}{*}{ PPESTSSR24* } & 11 & 1 & 0 & 0 & 1 & 1 & 1 & 0 & 1 & 0 & 0 & 0 & 0 & 0 & 0 & 1 & & 0 \\
\hline & 12 & 1 & 1 & 1 & 1 & 1 & 1 & 1 & 1 & 1 & 1 & 1 & 1 & 1 & 1 & 1 & 1 & 1 \\
\hline \multirow[t]{2}{*}{ PPESTSSR28 } & 1 & 0 & 0 & 0 & 0 & 0 & 0 & 0 & 0 & 0 & 0 & 0 & 0 & 0 & 1 & 1 & 0 & 0 \\
\hline & 83 & 1 & 1 & 1 & 1 & 1 & 1 & 1 & 1 & 1 & 1 & 1 & 1 & 1 & 0 & 1 & 1 & 1 \\
\hline \multirow[t]{2}{*}{ PPESTSSR30* } & 202 & 1 & 1 & 1 & 1 & 1 & 1 & 1 & 1 & 1 & 1 & 1 & 1 & 1 & 1 & 1 & 1 & 1 \\
\hline & 204 & 0 & 0 & 1 & 0 & 0 & 0 & 0 & 0 & 0 & 1 & 1 & 1 & 0 & 0 & 0 & 0 & 0 \\
\hline \multirow[t]{2}{*}{ PPESTSSR32* } & 200 & 1 & 1 & 0 & 1 & 1 & 1 & 1 & 1 & 1 & 1 & 1 & 1 & 1 & 0 & & 0 & 0 \\
\hline & 206 & 1 & 0 & 1 & 0 & 1 & 0 & 0 & 0 & 0 & 1 & 1 & 1 & 1 & 1 & 1 & 1 & 1 \\
\hline \multirow[t]{2}{*}{ PPESTSSR33 } & 231 & 1 & 1 & 1 & 1 & 1 & 1 & 1 & 1 & 1 & 1 & 1 & 1 & 1 & 1 & 1 & 1 & 1 \\
\hline & 241 & 0 & 0 & 1 & 0 & 0 & 0 & 0 & 0 & 0 & 0 & 1 & 0 & 1 & 0 & 0 & 0 & \\
\hline \multirow[t]{3}{*}{ PPESTSSR34* } & 242 & 0 & 1 & 0 & 0 & 0 & 1 & 0 & 1 & 1 & 1 & 1 & 1 & 1 & 0 & 0 & & 0 \\
\hline & & 0 & 0 & 0 & 0 & 0 & 0 & 0 & 0 & 0 & 0 & 0 & 0 & 0 & 0 & 0 & 0 & 1 \\
\hline & 26 & 1 & 1 & 1 & 1 & 1 & 1 & 1 & 1 & 1 & 1 & 1 & 1 & 1 & 1 & 1 & 1 & 1 \\
\hline \multirow[t]{2}{*}{ PPESTSSR43* } & $2 \xi$ & 1 & 1 & 1 & 1 & 0 & 0 & 1 & 1 & 1 & 1 & 1 & 1 & 1 & 0 & 0 & 0 & 1 \\
\hline & 291 & 1 & 1 & 0 & 1 & 1 & 1 & 1 & 1 & 1 & 0 & 0 & 1 & 0 & 1 & 1 & 1 & 1 \\
\hline \multirow[t]{2}{*}{ PPESTSSR44 } & 29 & 0 & 0 & 0 & 0 & 0 & 0 & 0 & 0 & 0 & 0 & 0 & 0 & 0 & 0 & 1 & & 1 \\
\hline & 297 & 1 & 1 & 1 & 1 & 1 & 1 & 1 & 1 & 1 & 1 & 1 & 1 & 1 & 1 & 1 & & \\
\hline \multirow[t]{2}{*}{ PPESTSSR48* } & 295 & 1 & 1 & 1 & 1 & 1 & 1 & 1 & 1 & 1 & 1 & 1 & 1 & 1 & 0 & 1 & 0 & \\
\hline & 298 & 1 & 0 & 1 & 0 & 1 & 1 & 1 & 0 & 0 & 0 & 0 & 0 & 0 & 1 & 0 & 1 & 1 \\
\hline
\end{tabular}

EST $=$ expressed sequence tag; SSR $=$ simple sequence repeat; $\mathrm{PCR}=$ polymerase chain reaction.

${ }^{\mathrm{z}}$ The markers suffixed with * indicates the nine ones that allow discriminating the 18 accessions.

${ }^{\mathrm{y}}$ See list of accessions in Table 1.

both of which possessed two dinucleotide motifs with a high number of repeats of around 30 (Table 2). Therefore, other similar compound SSRs should be excluded.

In conclusion, 37 high quality, i.e., without stutter band interference, EST-SSR markers have been developed and successfully applied for peach cultivar discrimination and hybrid authentication. Besides, it was observed that selection of suitable SSR markers, simple ones with motifs containing at least three nucleotides and compound ones with low number of repeats for each motif, dinucleotide motif allowed, is the most effective way to avoid the stuttering problem encountered during SSR-PCR amplification. and RAPD markers in peach. Theor. Appl. Genet. 87:805-815.

Chen, C.X., C.H. Bock, W.R. Okie, F.G. Gmitter, S. Jung, D. Main, T.G. Beckman, and B.W. Wood. 2014. Genome-wide characterization and selection of expressed sequence tag simple sequence repeat primers for optimized marker distribution and reliability in peach. Tree Genet. Genomes 10:1271-1279.

Cipriani, G., G. Lot, W.G. Huang, M.T. Marrazzo, E. Peterlunger, and R. Testolin. 1999. AC/GT and $\mathrm{AG} / \mathrm{CT}$ microsatellite repeats in peach [Prunus persica (L) Batsch]: Isolation, characterisation and cross-species amplification in Prunus. Theor. Appl. Genet. 99:65-72.

Dirlewanger, E., P. Cosson, M. Tavaud, M. Aranzana, C. Poizat, A. Zanetto, P. Arús, and F. Laigret. 2002. Development of microsatellite markers in peach [Prunus persica (L.) Batsch] and their use in genetic diversity analysis in peach and sweet cherry (Prunus avium L.). Theor. Appl. Genet. 105:127-138.

Edwards, A., A. Civitello, H.A. Hammond, and C. T. Caskey. 1991. DNA typing and genetic mapping with trimeric and tetrameric tandem repeats. Am. J. Hum. Genet. 49:746-756.

Gawel, N.J. and R.L. Jarret. 1991. A modified CTAB DNA extraction procedure for Musa and Ipomoea. Plant Mol. Biol. Rpt. 9:262-266.

Goulão, L. and C.M. Oliveira. 2001. Molecular characterisation of cultivars of apple (Malus $\times$ domestica Borkh.) using microsatellite (SSR and ISSR) markers. Euphytica 122:81-89.

Guichoux, E., L. Lagache, S. Wagner, P. Chaumeil, P. Léger, O. Lepais, C. Lepoittevin, T. Malausa, E. Revardel, F. Salin, and R.J. Petit. 2011. Current trends in microsatellite genotyping. Mol. Ecol. Resour. 11:591-611.

Hite, J.M., K.A. Eckert, and K.C. Cheng. 1996 Factors affecting fidelity of DNA synthesis during PCR amplification of d(C-A)n.d(G-T)n microsatellite repeats. Nucleic Acids Res. 24:2429-2434.

Huang, J.F., Y.H. Qin, H.X. Miao, C.Y. Zhang, Z.X. Ye, and G.B. Hu. 2012. Molecular marker analysis of 'Shatangju' and 'Wuzishatangju' mandarin (Citrus reticulata Blanco). Afr. J. Biotechnol. 11:15501-15509.

Huang, S.W., B.X. Zhang, D. Milbourne, L. Cardle, G.M. Yang, and J.Z. Guo. 2000. Development of pepper SSR markers from sequence databases. Euphytica 117:163-167.

Jones, C.J., K.J. Edwards, S. Castaglione, M.O. Winfield, F. Sala, C. van deWiel, G. Bredemeijer, B. Vosman, M. Matthes, A. Daly, R. Brettschneider, P. Bettini, M. Buiatti, E. Maestri, A. Malcevschi, N. Marmiroli, R. Aert, G. Volckaert, J. Rueda, R. Linacero, A. Vazquez, and A. Karp. 1997. Reproducibility testing of RAPD, AFLP and SSR markers in plants by a network of European laboratories. Mol. Breed. 3:381-390.

Aranzana, M.J., J. Garcia-Mas, J. Carbó, and P. Arús. 2002. Development and variability analysis of microsatellite markers in peach. Plant Breed. 121:87-92.

Caruso, M., C.T. Federici, and M.L. Roose. 2008. EST-SSR markers for asparagus genetic diversity evaluation and cultivar identification. Mol. Breed. 21:195-204.

Cavagnaro, P.F., D.A. Senalik, L.M. Yang, P.W. Simon, T.T. Harkins, C.D. Kodira, S.W Huang, and Y.Q. Weng. 2010. Genome-wide characterization of simple sequence repeats in cucumber (Cucumis sativus L.). BMC Genom. 11:569.

Chaparro, J.X., D.J. Werner, D. O'Malley, and R.R. Sederoff. 1994. Targeted mapping and linkage analysis of morphological, isozyme,
Li, X.W., X.Q. Meng, H.J. Jia, M.L. Yu, R.J. Ma, L.R. Wang, K. Cao, Z.J. Shen, L. Niu, J.B. Tian, M.J. Chen, M. Xie, P. Arus, Z.S. Gao, and M.J. Aranzana. 2013. Peach genetic resources: Diversity, population structure and linkage disequilibrium. BMC Genet. 14:84.

Liu, K. and S.V. Muse. 2005. PowerMarker: An integrated analysis environment for genetic marker analysis. Bioinformatics 21:2128-2129.

Monte-Corvo, L., L. Goulão, and C. Oliveira. 2001. ISSR analysis of cultivars of pear and suitability of molecular markers for clone discrimination. J. Amer. Soc. Hort. Sci. 126:517-522.

Olejniczak, M. and W.J. Krzyzosiak. 2006. Genotyping of simple sequence repeats factors implicated in shadow band generation revisited. Electrophoresis 27:3724-3734. 
Page, R.D.M. 1996. TreeView: An application to display phylogenetic trees on personal computers. Comput. Appl. Biosci. 12:357-358.

Quarta, R., M.T. Dettori, I. Verde, A. Gentile, and Z. Broda. 1998. Genetic analysis of agronomic traits and genetic linkage mapping in a $\mathrm{BC} 1$ population using RFLPs and RAPDs. Acta Hort. 465:51-59.

Rajapakse, S., L.E. Belthoff, G. He, A.E. Estager, R. Scorza, I. Verde, R.E. Ballard, W.V. Baird, A. Callahan, R. Monet, and A.G. Abbott. 1995. Genetic linkage mapping in peach using morphological, RFLP and RAPD markers. Theor. Appl. Genet. 90:503-510.

Sambrook, J., E.F. Fritsch, and T. Maniatis. 1989. Molecular cloning: A laboratory manual, 2nd ed. Cold Spring Harbor Laboratory Press, New York, NY.

Schuelke, M. 2000. An economic method for the fluorescent labeling of PCR fragments. Nat. Biotechnol. 18:233-234.

Seo, S.B., J.Y. Ge, J.L. King, and B. Budowle. 2014. Reduction of stutter ratios in short tandem repeat loci typing of low copy number DNA samples. Forensic Sci. Int. Genet. 8:213-218.

Song, Q.J., E.W. Fickus, and P.B. Cregan. 2002. Characterization of trinucleotide SSR motifs in wheat. Theor. Appl. Genet. 104:286-293.

Sosinski, B., M. Gannavarapu, L.E. Hager, G.J. Beck, C.D. King, S. Ryder, W.V. Rajapakse,
R.E. Baird, and A.G. Ballard. 2000. Characterization of microsatellite markers in peach (Prunus persica (L.) Batsch). Theor. Appl. Genet. 101:421-428.

Sun, J.M., H. Yin, L.T. Li, Y. Song, L. Fan, S.L. Zhang, and J. Wu. 2015. Evaluation of new IRAP markers of pear and their potential application in differentiating bud sports and other Rosaceae species. Tree Genet. Genomes 11:25.

Tautz, D. 1989. Hypervariability of simple sequences as a general source for polymorphic DNA markers. Nucleic Acids Res. 17:64636471.

Testolin, R., T. Marrazzo, G. Cipriani, R. Quarta, I. Verde, M.T. Dettori, M. Pancaldi, and S. Sansavini. 2000. Microsatellite DNA in peach (Prunus persica L. Batsch) and its use in fingerprinting and testing the genetic origin of cultivars. Genome 43:512-520.

Teulat, B., C. Aldam, R. Trehin, P. Lebrun, J.H.A Barker, G.M. Arnold, A. Karp, L. Baudouin, and F. Rognon. 2000. An analysis of genetic diversity in coconut (Cocos nucifera) populations from across the geographic range using sequence-tagged microsatellites (SSRs) and AFLPs. Theor. Appl. Genet. 100:764-771.

Thiel, T., W. Michalek, R.K. Varshney, and A. Graner. 2003. Exploiting EST databases for the development and characterization of gene-derived
SSR-markers in barley (Hordeum vulgare L.). Theor. Appl. Genet. 106:411-422.

Vendramin, E., M.T. Dettori, J. Giovinazzi, S. Micali, R. Quarta, and I. Verde. 2007. A set of EST-SSRs isolated from peach fruit transcriptome and their transportability across Prunus species. Mol. Ecol. Notes 7:307-310.

Wang, W.T., C. Feng, Z.H. Zhang, L.J. Yan, M.M. Ding, C.J. Xu, and K.S. Chen. 2016. Development of highly polymorphic expressed sequence tags-simple sequence repeat markers and their application in analysis of genetic diversity of Chinese bayberry (Morella rubra). HortScience 51:227-231.

Wünsch, A. and J.I. Hormaza. 2002. Molecular characterisation of sweet cherry (Prunus avium L.) genotypes using peach [Prunus persica $(\mathrm{L}$.) Batsch] SSR sequences. Heredity 89:56-63.

Xu, Y., R.C. Ma, H. Xie, J.T. Liu, and M.Q. Cao. 2004. Development of SSR markers for the phylogenetic analysis of almond trees from China and the Mediterranean region. Genome 47:1091-1104.

Zhao, G.L., H.Y. Dai, L.L. Chang, Y. Ma, H.Y. Sun, P. He, and Z.H. Zhang. 2010. Isolation of two novel complete Ty1-copia retrotransposons from apple and demonstration of use of derived S-SAP markers for distinguishing bud sports of Malus domestica cv. Fuji. Tree Genet. Genom. 6:149-159. 